\title{
Migration in the Process of Establishing Settlement Patterns in Langsa City, Aceh during the New Order Era
}

\author{
Sumiyati ${ }^{*}$, Singgih Tri Sulistiyono ${ }^{1}$, and Yety Rochwulaningsih ${ }^{1}$ \\ ${ }^{1}$ Doctoral Program of History, Faculty of Humanities, Universitas Diponegoro, Semarang
}

\begin{abstract}
This article examines the problem of why ethnic migration stimulates the formation of settlement patterns and how the construction of these settlement patterns is. By using the critical historical method, the results show that the city of Langsa was an "open" city since its inception and the most accessible in Aceh during the New Order Era. In New Order Era, through the transmigration program, facilitated an increasing flow of migration, thus increasing the number of Javanese ethnics who migrated in the area. Most of the migration was mainly driven by economic aspect. Langsa and its surrounding areas since colonial times have grown and developed into centers of economic activity. There several strategic commodities in Langsa, namely pepper, coffee, and mining. Ethnic groups who migrated in Langsa, among others; Aceh Sigli, Aceh Tamiang, Java, Minang, Batak, Chinese, and others where they tend to maintain their ethnic identity. From the various ethnicities, some of them, such as Acehnese, Minang, Javanese, and Chinese, then construct settlement patterns according to their respective ethnic backgrounds. This is reflected in the names of settlements such as Sukajadi Kebun Ireng, Gedubung Jawa, and Asem Peutik are settlements of Javanese ethnicity.
\end{abstract}

\section{Introduction}

Several Several researchers pay considerable attention to ethnic migration and the formation of new space; for instance, Zukin points out the role of ethnic diversity in shaping places and spaces and then relates it to the tendency to modify cosmopolitan lifestyles and turn them into a vital resource for urban prosperity and growth [1]. Furthermore, Jock Collins and Patrick Kunz investigated how ethnicity shapes public spaces in four ethnic precincts in Sydney, namely Chinatown, Little Italy, Auburn (Little Turkey) and Cabramatta ('Vietnamatta'). It demonstrates the significant role of immigrant entrepreneurs in the emergence of the ethnic economy in general and ethnic precincts in particular in the cosmopolitan city [2]. Nevertheless, the study of historical traces of migration and settlement patterns in the Langsa area of East Aceh during the New Order era is still neglected, especially in terms of the migration and adaptation processes. Historical evidence shows that long before the Dutch established their power in the archipelago, Langsa in East Aceh had

\footnotetext{
*Corresponding author: sumiyatisumabindulhamid@gmail.com
} 
been settled by migrants from various regions in the archipelago. Langsa has been an open city since the time of the Iskandar Muda Sultanate, which was marked by the existence of the Mandjapahit area in the south of Langsa, which was also part of the Kedjoeroean Langsar before the 20th century [3]. The name is thought to be linked to the attempt by the Majapahit Kingdom to annex the area in the 14th century, which resulted in the conquer of Haru, Tumihang, Parlak and Samudra [4]. The presence of ethnic groups outside Aceh who came to this area had ushered in a new area in Langsa Aceh Timur. During the colonial period, Langsa was known for its ethnic diversity, reflected in the establishment of new settlements after the arrival of Javanese people who migrated as plantation and mining workers. The politics of "economic exploitation" imposed by the Dutch colonial government through plantations and mining operations in the early twentieth century was the main factor for the arrival of Javanese ethnicity to the East Aceh region. The economic motive to improve livelihoods has been a primary reason for the migration of members of an ethnic group.

The first rubber plantation was opened in Langsa in 1907, followed by oil palm cultivation and petroleum exploration in the following years. This increase in economic activity required human resources that the residents of Langsa could not fill. As a result, workers from outside Langsa were brought in, including Javanese. The first group of 842 Javanese arrived in East Aceh in 1910. Their number continued to grow until the third decade of the 20th century, reaching tens of thousands [5].

The migration of Javanese and other ethnic people to Langsa East Aceh as plantation workers creates an interconnectedness between the economic sector and the social life of the communities in an area. The presence of these migrants had created a new social order and turned homogeneous communities into diverse ones. Based on the above background, the problems are reflected by the question, why ethnic migration stimulates the formation of population settlement patterns and how the construction of population settlement patterns remains to display ethnic identity. Therefore, this paper aims to; 1) identify the process of migration of several ethnic groups that took place massively in Langsa during the New Order; 2) describe the pattern of settlements based on ethnic background; and 3) analyze the relationship between ethnic migration and settlement patterns with ethnic backgrounds in Langsa, East Aceh.

\section{Method}

The article applied the historical method, a systematic set of rules and principles to collect historical sources effectively, evaluate them critically and present a synthesis of the results achieved in analytical writing [6]. There are four stages of activity, namely heuristics (collection of historical/data sources), criticism (internal and external), interpretation through data synthesis and analysis, and historiography [7]. This method is used to explain and find arguments for the facts related to the research problem. The primary data sources were obtained from the colonial archives on Langsa, and the national archives of the Republic of Indonesia/ANRI, the archives of the Langsa City Transmigration Service, the archives at the Langsa City Statistics Office and the Provincial Government of Nangroe Aceh Darussalam as well as oral histories from interviews with informants. Secondary data sources are obtained from articles in journals and reference books that are relevant to the problems studied. 


\section{Results and Discussion}

\subsection{Migration and the Formation of Ethnic Areas during the Colonial Period}

The emergence of pepper as the most important commodity in Southeast Asia in the 16th and 17th centuries resulted in the expansion of pepper plantations to East Aceh by ulèëbalang from Aceh Besar and Pasai. Pepper plantations were directly linked to the influx of migrants from Aceh Besar and Pasai to East Aceh, including pepper plantations in Langsa. Pepper production from Langsa was recorded at thirty koyan in 1875. In 1875 the population of Kedjoeroean Langsar, Mandjapait, Raja Toeah and Bajan was around 6000 people [8].

Apart from plantations, Langsa attracted outside traders, especially from Pase and Pidie, who accounted for the majority of the population [9]. According to researchers, people from Pidie opted to work as traders, choosing settlements in marketplaces along Jalan Ahmad Yani or main roads, taking advantage of Langsa as a strategic trading town, thanks to its proximity to the Malacca Strait and the growth of Kuala Langsa Port. Some of the sigli ethnic groups choose to work as fishermen and live in coastal areas or near Kuala Langsa. There is a Sigli ethnic settlement called Telaga Tujuh Village on a small island off the coast of Kuala Langsa. Denagan still maintains the seven elements of Pidie culture, which are still well preserved.

In addition to the Pidie, Javanese also became part of the diverse community. Plantations were the main pull that drew Javanese to Langsa. The first wave of Javanese migration to Langsa to work at rubber plantations began in 1910, involving 842 people. The expansion of plantation areas further attracted more labourers. In 1938 the number of Javanese labourers had risen to 22,199 , both working on contract and independently [10].

This resulted in Javanese workers becoming the majority ethnic group in the plantation community. Apart from labourers brought directly from Java Island, Javanese in Langsa also included those who had escaped from plantations in East Sumatra. To regulate workers on Langsa's plantations, including Chinese labourers, the Colonial Government established Coolie Ordinance Atjehand Dependencies No. 334 in 1916 [10].

Economic activities involving foreign workers in the colonial period led to diverse ethnicities who settled in Langsa, including Europeans, foreign Easterners, and indigenous people (Bumiputras). Population census data in 1914 shows that the number of people who lived in Langsa and Tamiang stood at 40,203 people comprising 186 Europeans, 24,656 Acehnese, 11,893 indigenous Langsa and Tamiang people, 3,277 ethnic Chinese, 191 other Eastern foreigners, and 7,940 Javanese (contract labourers) [11]. Ethnic diversity during the colonial period spawned settlements based on ethnicities such as the Javanese and Malay Gampong (kampongs), Sukajadi KebunIreng, Javanese Gedubung, and Asem Peutik [12] and other ethnic areas such as Gedubang Aceh and others.

\subsection{Strengthening of Ethnic Areas during the New Order Perior}

Until the independence period, Javanese ethnicity in Langsa still worked as labourers in various plantations spread across Langsa. In the economic field, Indonesian independence prompted the nationalization of foreign companies intended to benefit the Indonesian people. The nationalization of these foreign companies in Langsa resulted in the Dutch and Japanese plantations takeover by the Indonesian government, which created a plantation company called Perusahaan Negara Perkebunan (PNP). The plantation companies in Langsa came under PNP-1 [13]. Workers from Java were retained as labourers at PNP-1 under a work agreement or contract system. 
The nationalization of foreign plantations, ostensibly to bring welfare to the Indonesian people, turned out to be just a dream, especially for the Javanese labourers. After the nationalization, the lives of the Javanese turned for the worse. Despite their status as contract workers under PNP I, their fate was in limbo. They could not return to their hometowns after their work contracts expired because they had no money [14] as PNP-1 could not pay their wages.

The Javanese who had their contracts expired looked for other jobs as casual labourers outside the plantations to survive in Langsa. They then formed new settlements, which led to the establishment of "ethnic Javanese" settlements, adopting Javanese names as Sidodadi, Sidorejo, Selalah, Pondok Kemuning, Sukajadi, Kebun Ireng, Gedubang Jawa, and Asam Peutik.

\subsection{Adaptation and Adoption Process}

The establishment of ethnic settlements by former contract workers at PNP-1, known as PTPN 1, also called Kebun Lama by locals, began by clearing land to live and grow crops around PNP-1 plantations and empty land belonging to Ulebalang Langsa. In 1967, the Javanese paid Ulebalang named Ali Basah for their cultivated land and converted it into an ethnic Javanese settlement called Siderjo. The same process goes for establishing the Sidodadi village; however, the former labourers bought the land from PNP 1 [15], until finally, they joined a government program called Prona [8]. Today, ethnic villages or settlements have been established surrounding the PTPN 1 plantations, including Selalah, Sidorjo, Sidodadi, Asam Betik, and Pondok Kemuning Gedubang Jawa [16].

The formation of an ethnic area around PTPN 1 langsa in 1968. Even the Asam Betik village had existed since 1942. However, several villages were not included in the Regional Map, such as Sidodadi, Siderjo, Selalah, Gedubang Jawa. Only a few areas made it to the map of Indonesia, including Asam Betik, which was categorized as a forest area [17]. In the 1970s, Javanese arts and culture were still well-preserved in Siderjo Village, while other art forms such as Ludruk and Wayang were losing ground thanks to globalization. Cultural elements that are still well preserved include dialects, wedding and funeral customs. Traditions still observed include Lebaran ketupat, which is celebrated after completing six days of fasting in the month of Shawal. On Lebaran Ketupat, people serve a variety of foods, including ketupat and vegetable soup. Known to Acehnese as 'Puasa Nam', The fasting period starts on the second day of Eid al-Fitr and lasts for six days [18].

\subsection{Transmigration in Strengthening Ethnic Areas}

During the New Order era starting from Repelita I (1969-1974), the Javanese transmigration program launched by the government aimed to revive the economy and open up wider employment opportunities outside Java [3]. In practice, the transmigration policy encouraged a growing number of ethnic Javanese who moved to Langsa and finally chose to live permanently with their families.

The first wave of transmigration to East Aceh occurred in 1983 involving migrants from Serdang Regency, West Java. The migration to East Aceh was carried out after the success of the transmigration program in several other areas in Aceh, including one involving 100 families to Blang Peutek, Padang Tiji, Pidie Regency in 1964. In 1976 the transmigration program again brought in 300 families to Cot Girek, North Aceh District. In 1978, based on Presidential Decree No. 7 of 1978, Aceh was designated as a transmigrant recipient province, which resulted in thousands of family heads (KK) entering the Aceh region. The presence of Javanese transmigrants increased the population of the Langsa community. In 
1985 the total population of Langsa City was 96,106 people, spread over 77 villages and 18,521 households [20].

The first batch of transmigrants to East Aceh were 250 families who relocated to the CT-5 location. These migrants started from scratch, and then in 1987, their status was promoted to transmigrants of Perkebunan Inti Rakyat (PIR) [21].

In 1998 CT-5 was renamed Desa Bukit Makmur in Julo District, East Aceh Regency. Another Javanese transmigrant village in Langsa East Aceh is Desa Transmigrasi Air Terjun, which migrants have settled from West Java and other parts of Java Island since 1987. In addition, there is also Kampung Bandung, where the early Javanese transmigrants settled in Langsa.

Transmigration as the Government's Program to Maintain Economic and Political Stability is a reasonable objective because Javanese migrants have become agents to maintain the stability of the state, making it the only economic program tied to national defence and security considerations [19]. In Gampong, most of the population are Javanese. The number of Acehnese is small because most of the area Oil palm plantations are inhabited by a variety of people, but most of them are Javanese [23].

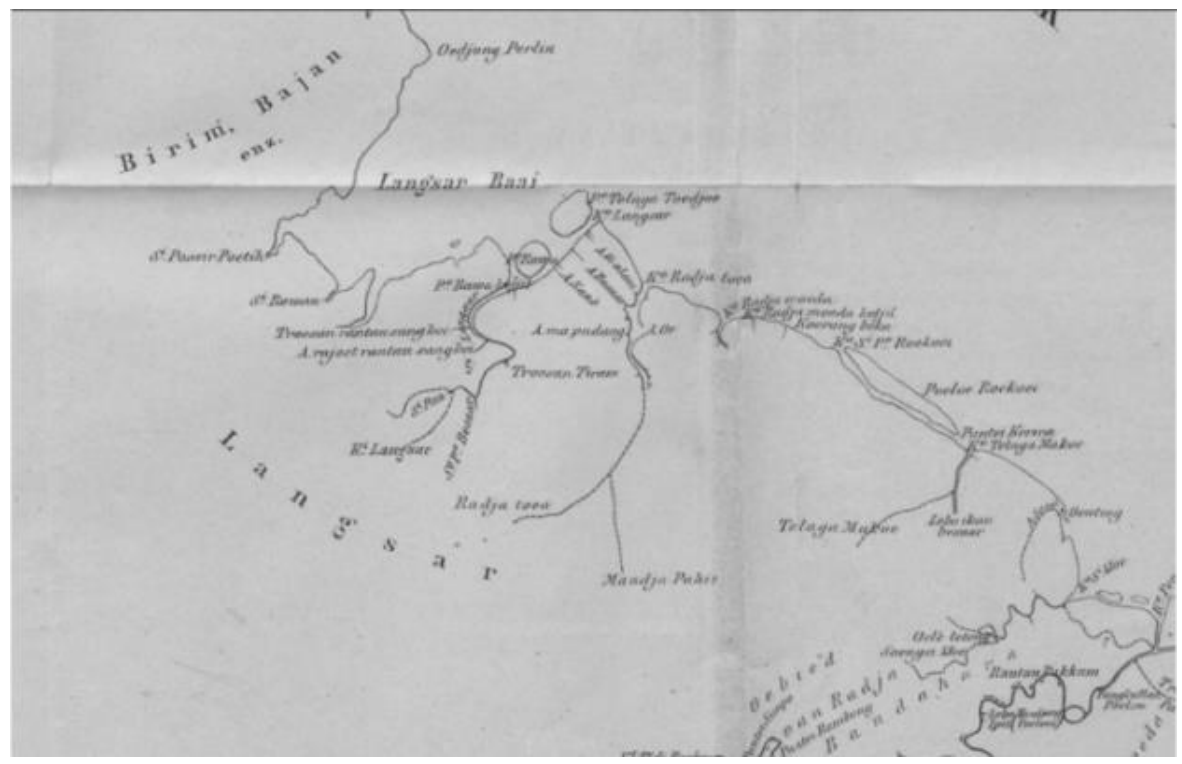

Fig. 1. Map of Langsa, Source: J.A. Kruijt, 1877: 98. 


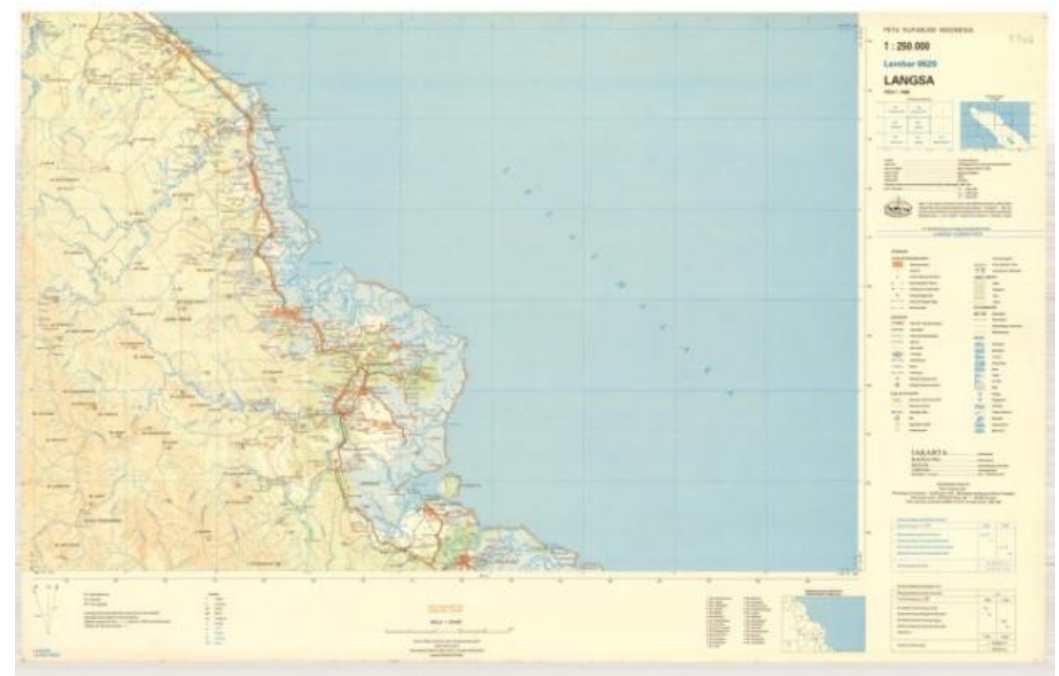

Fig. 2. Indonesian Topographical Map - Langsa by ANRI 1: 250.000, 1987.

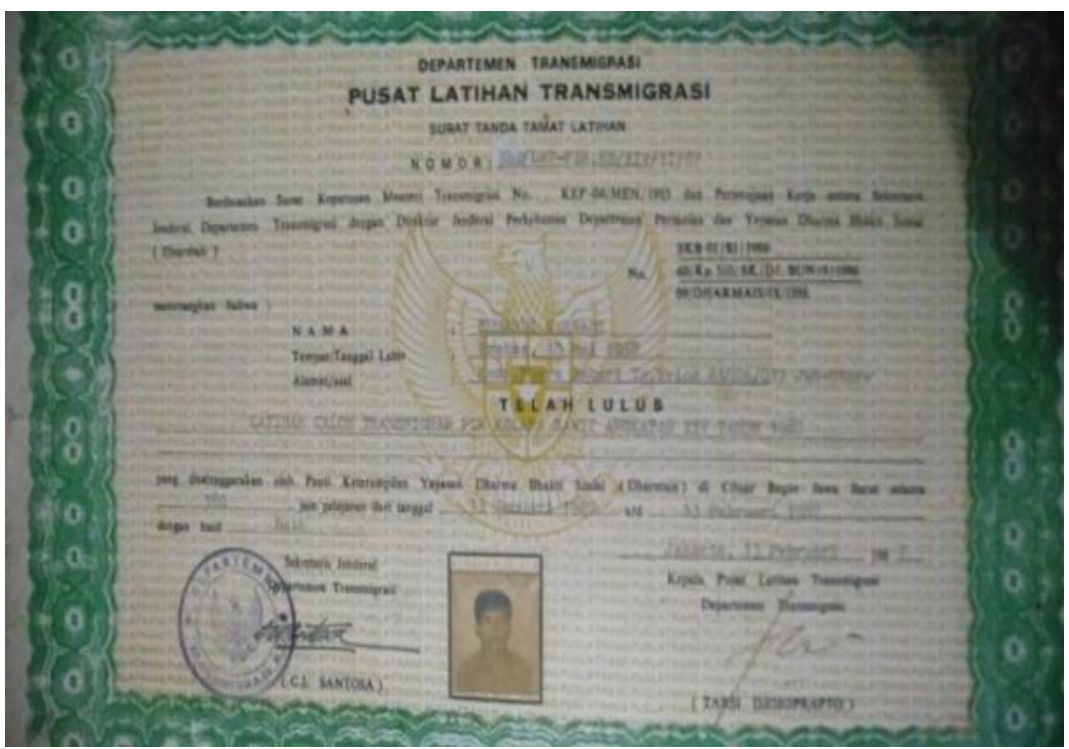

Fig. 3. Certificate of Training given to Would-be Transmigrants who were to be sent to Pir Sus II Aluer Punti Langsa, East Aceh. Source: Transmigrant 1987.

\section{Conclusion}

The establishment of ethnic settlements in Langsa had occurred since the colonial period. This is supported by Langsa's geographically strategic position in the maritime constellation in Southeast Asia, opposite the Strait of Malacca. During the colonial period, the policies pursued were to strengthen and develop ethnic areas as a political strategy for control and prevent the consolidation of resistance to the colonial government. In its economic expansion, the colonial government opened up "space" for the flow of foreign ethnic migrations to Langsa as plantation workers, mining and pepper as the most important commodities in Southeast Asia. 
This policy paved the way for the influx of people from ethnic Sigli in Aceh Besar and Pasai to Langsa for commercial purposes, followed by other ethnicities for the same interests. From this, naturally formed ethnic villages. After independence, especially during the New Order era, the expansion of ethnic settlements in Langsa was growing, shown by the emergence of ethnic villages around plantations belonging to the company, which is now called PTPN 1.

Ethnic migration stimulated the formation of ethnic-based settlements, the pattern of which is inseparable from the socio-cultural values that frame economic activity. Each ethnic group feels more "comfortable" socially and culturally if they are in the same ethnic environment, even though they are also open to interacting with other ethnic communities. A group of people sharing the same fate, ethnic identity and aspirations have resulted in villages whose populations share an ethnic identity. This is a process of the life history of migrants. Likewise, adapting to nature and accepting a new culture and striving to maintain the old culture is the most important part of the strategy for migrants to a new place.

\section{References}

1. S. Zukin, The cultures of cities, Blackwell, Oxford (1995)

2. J. C. a. P. Kunz, Ethnicity and Public Space in the City: Ethnic Precincts in Sydney, Cosmopolitan Civil Societies Journal, 1(11), 39-70 (2009)

3. J. Kruijt, Atjeh en de Atjehers Twee Jaren Blokkade op Sumatra's Noord-oost-kust, Gualth Kolff Leiden (1877)

4. D. Lombard, Nusa Jawa: Silang Budaya Kajian Sejarah Terpadu Bagian II: Jaringan Asia, Gramedia Pustaka Utama Jakarta (1996)

5. Congresverslag, Beschrijvende catalogus harer inzendingen met een kort overzichtvan het cultuurgebied van Sumatra's Oostkust en Atjeh, International rubber congres en tenttoon stelling, Batavia (1914)

6. G. J. Garraghan, A Guide to Historical Method, Fordham University Press New York, 18 (1957)

7. L. Gottschalk, Understanding History, Translator: Nugroho Notosusanto, Universitas Indonesia Press Jakarta, 32 (1986)

8. Wikipedia, Badan Pertahanan Nasional (2021) Retrieved from: https://id.wikipedia.org/wiki/Badan Pertanahan Nasional

9. D. Rachmatsyah, Menelusuri Jejak Sejarah Langsa, Sekretariat Daerah Pemerintah Kota Langsa (2017)

10. Verslag van Arbeidsispectie (1910-1938)

11. Congresverslag.loc.cit

12. Topographische Inrichting Atjeh en Onderhoorigheden, Batavia (1917)

13. PP Nomor 14 tentang Pendirian Perusahaan Negara Perkebunan (1968)

14. Banjak buruh PNP 1 belum tentu nasibnya, Harian Waspada (May, 1969)

15. Suhardi, Interviewee, [Interview] (May, 2021)

16. Sketsa wilayah atau desa etnik di sekitar PTPN 1. [Art].

17. Lampiran 2 Peta Rupa Bumi Indonesia Langsa oleh ANRI 1: 250.000 
18. Suara Publik, Anggota DPR Aceh H. Asnawi Bersama Komunitas Jawa Rayakan Tradisi Lebaran Ketupat (2021) Retrieved from: https://suarapublik.co.id/politik/anggota-dpr-aceh-asrizal-h-asnawi-bersamakomunitas-jawa-rayakan-tradisi-lebaran-ketupat/

19. H. Heeren, Transmigrasi di Indonesia, Gramedia Jakarta (1979)

20. Kantor Statistik Aceh Timur tahun (1985)

21. U. Pelly, Etnisitas dalam Politik Multikultural, Casa Mesra Puslisher Yogyakarta (2016)

22. P. Levang, Ayo Ke Tanah Sabrang Transmigrasi di Indonesia, Montpellier institut de recherché Pour Le Developpent Forum Jakarta (2003)

23. Y. F. a. Y. Amri, Stuck in Sharia Space: The Experiences of Christian Students in Langsa, Aceh, Al-Jāmi‘ah: Journal of Islamic Studies - ISSN: 0126-012X (p); 23560912 (e), 59(11), 33-56 (2021) 